\title{
LUT
}

Lappeenranta

University of Technology

\section{Dynamic capabilities in MNCs: subsidiary international business competence in the Finnish-Russian context}

Pronina Mariia, Kuivalainen Olli, Torkkeli Lasse, Gracheva Polina

This is a Pre-print version of a publication

published by Inderscience Enterprises Ltd

in International Journal of Multinational Corporation Strategy

DOI: $\quad 10.1504 /$ IJMCS.2016.079453

Copyright of the original publication: () 2019 Inderscience Enterprises Ltd.

Please cite the publication as follows:

Pronina, Mariia. Kuivalainen, Olli. Torkkeli, Lasse. Gracheva, Polina. (2016). Dynamic capabilities in MNCs: subsidiary international business competence in the Finnish-Russian context. International Journal of Multinational Corporation Strategy, Vol. 1, No. 2. p. 87-106. DOI: 10.1504/IJMCS.2016.079453 
https://doi.org/10.1504/IJMCS.2016.079453

\title{
Dynamic capabilities in MNCs: subsidiary international business competence in the Finnish-Russian context
}

\section{Mariia Pronina, Olli Kuivalainen*, Lasse Torkkeli, Polina Gracheva}

\begin{abstract}
What competencies do companies need to develop in order to internationalize successfully? In this paper our focus is on the dynamic capabilities and, particularly, international business competence of the Russian subsidiaries of Finnish multinational corporations (MNCs) operating in the rapidly changing market. By analysing the internationalization process of two Finnish MNCs, and especially their (small) subsidiaries' internationalization process in Russia, we seek to illustrate the international business competence development of subsidiaries. Small and medium-sized enterprises need international business competence in order to handle export activities or internationalize. Here we explore how the development of international business competence in the subsidiaries of MNCs occurs and to what extent the subsidiaries should possess international business competence in order to operate successfully. Our results indicate that the underlying dynamic is that MNC subsidiaries derive advantages from their local presence and local employees, advantages unique to the MNC subsidiary environment, advantages that facilitate the high level of international business competence. Our main contribution is to bring out the interplay between the parent company and the small subsidiary in international business competence literature. Furthermore, we extend the knowledge on the internationalization of MNCs from developed economies entering Russia.
\end{abstract}


Keywords: MNC, international business competence, international business in Russia

\section{INTRODUCTION}

The growing phenomenon of small firm's internationalization since the early 1990s has raised the question of what competencies they need to develop in order to internationalize successfully (Knight and Cavusgil, 2004; Knight and Kim, 2009; Kuivalainen et al., 2010). The early international business (IB) literature emphasized market knowledge (cf. e.g. Johanson and Vahlne, 1977). According to this view, the internationalization process often starts with export activities - requiring both the acquisition of target market information and knowledge in order to answer to the foreign market's challenges - and the effective utilization of internal or external resources (Belich and Dubinskiy, 1995).

While there are many terms used for the required competencies for successful internationalization, in this paper we focus on a multidimensional concept called international business competence, which is defined as the degree of adoption of "a bundle of international competences to carry out international business activities ... in an effective way" (Knight and Kim, 2009, p.260). International business competence is discussed in the literature on international business mostly within the context of small and medium-sized enterprises (SMEs) (Belich and Dubinskiy, 1995; Knight and Kim, 2009). When engaging in export activities - or internationalizing in other ways - SMEs tend to be in a weaker position compared to the betterresourced large corporations (Autio et al., 2000; Knight and Kim, 2009) and hence the possession of the "right bundle" or of competencies can be critical.

Already in the early internationalization step, in order for firms to be successful in export activities, they need to develop the ability to manage several tasks relevant to business and the cultural and trade environment (Belich and Dubinsky, 1995). In order to internationalize, SMEs need to act in an innovative manner to be able to overcome their lack of resources. Thus, 
international business competence as an organizational dynamic capability can be a source of competitive advantage (Knight and Kim, 2009). Such a capability can also help companies develop the ordinary substantive capabilities they need in their daily operational activities (Barreto, 2010). Dynamic capabilities are defined as the "firm's ability to integrate, build and reconfigure internal and external competences to address rapidly changing environments" (Teece et al., 1997, p.516; see also Eisenhardt and Martin, 2000), a definition that suggests that these capabilities are increasingly required in changing and uncertain environments.

At the moment (as well as historically) Russia provides such an environment for conducting international business, yet the capability development in companies entering Russia has not been properly explained in extant research. Moreover, the focus of international business competence in SMEs has neglected the fact that multinational corporations (MNCs) also conduct such market entries, and the establishment of an MNC subsidiary in Russia, for instance, provides a business context distinct from that of individual, independent SMEs. Therefore, we do not yet know if the dynamics are similar and, indeed, if the benefits accrued by international business competence in SMEs also hold for other types of companies, such as MNCs.

In this paper, we seek to fulfil these gaps in the extant literature on international business by focusing on the international business competence of the Russian subsidiaries of Finnish MNCs operating in the rapidly changing Russian environment. By analysing the internationalization process of two Finnish MNCs, and especially their (small) subsidiaries' internationalization process in Russia, we aim at achieving deeper knowledge about the development of the subsidiary's international business competence (SIBC) in the context of MNC network theory. The research questions we seek to answer are: 1) How does the development of international business competence in the subsidiaries of MNCs occur? and 2) To what extent should the subsidiaries possess international business competence during their establishment and in 
subsequent operations? Our main contribution is to bring out the interplay between the parent and the small subsidiary in the international business competence and dynamic capability literature. Examining how international business competence develops also contributes to further explaining how dynamic capabilities are developed in practice, as the dynamic capability literature has prevalently discussed the topic conceptually. We suggest that while SIBC as a dynamic capability leads to the continuous learning-by-doing process of knowledge accumulation in the host country some factors present in a local business environment and culture (i.e. Russia in our context), may influence the direction on the SIBC development. Furthermore, we extend the knowledge on the internationalization of MNCs from developed economies entering Russia.

\section{THEORETICAL BACKGROUND}

\section{$\underline{\text { Definition }}$}

It is acknowledged that a number of terms and concepts have been used to describe international business competencies. For example, we can note the distinction between international competence and international business competence. The former is "the ability to handle relations with foreign suppliers", visible in exporting firms (Hallen, 1982). It consists of three areas: market knowledge, cultural awareness and trade techniques. An increase in the competence and knowledge on the procedures and conditions in foreign markets enables increasingly focused marketing and helps familiarize employees with foreign market conditions (Belich and Dubinskiy, 1995). Whereas international business competence is " $a$ multidimensional concept that reflects the extent to which the SME adopts a bundle of international competences to carry out international business activities in foreign markets in an effective way" (Knight and Kim, 2009, p.260). It captures the intangible cultural orientations and processes that account for the international business success of SMEs. It further reflects 
organizational competences in - for example, learning about international environments and adapting the organization to new environments when operating in foreign markets - the most important competences being international orientation, international marketing skills, international innovativeness and international market orientation (ibid.). We will consequently use the term international business competence although the international competence used by Hallen (1982) can be seen to comprise a conceptually similar set of skills.

\section{Business network theory}

Due to their internationally dispersed organizational form, large MNCs tend to hold better knowledge of foreign markets than SMEs (Knight and Kim, 2009). This suggests that MNCs, as knowledge repositories (cf. e.g. Kogut and Zander, 1993), by default should possess international business competence as entities. Yet the international business literature is not clear on whether the same applies to the international business competence of the (individual) subsidiaries of MNCs. Business network theory provides a lens through which we can examine this issue further as it discusses in detail both the relationships between the MNC and its environment. The theory, in which foreign market knowledge also occupies a central position, assumes that MNC subsidiaries are embedded in several business networks that influence most of their operations (Andersson et al., 2001; 2002). Specifically, each subsidiary of the MNC is locally embedded into the network of the host country market and is to some extent is autonomous from the networks of other MNC units. Network theory emphasizes the relationships of the external subsidiary, while the internal administrative interactions within the MNC are seen as complementary. The MNC in business network theory is illustrated in Figure 1. 


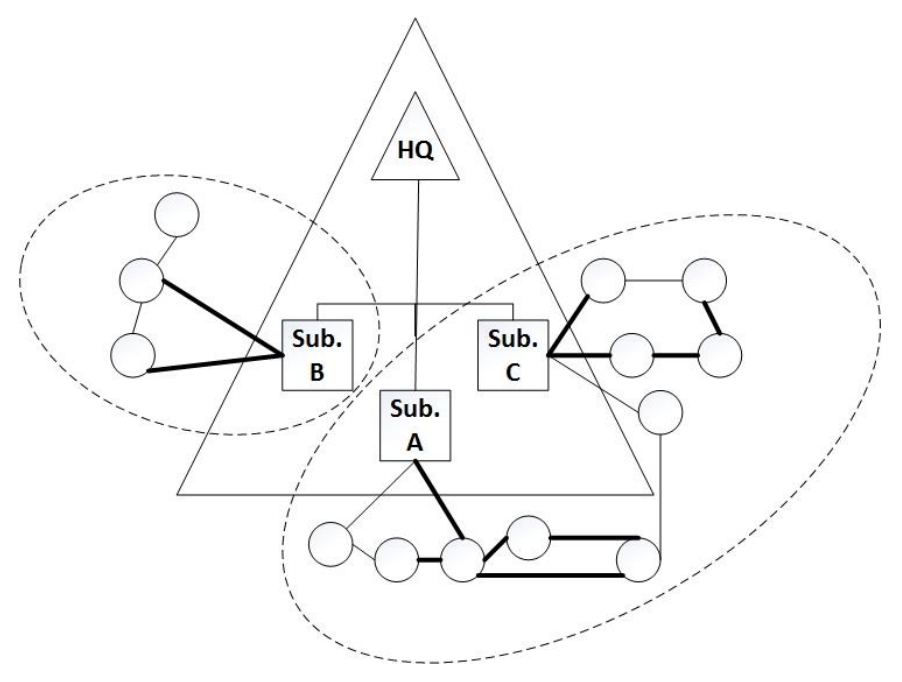

Figure 1. A MNC in a business network (adapted from Forsgren 2008).

As seen in the figure above, the theory posits that the $\mathrm{MNC}$, as the main triangle, including its headquarters (HQ) (the HQ triangle), is administratively connected with the subsidiaries (i.e. "Sub." blocks). The subsidiaries are then surrounded by business actors external to the MNC (the small circles). The relationships between them is divided into embedded exchanges (bold lines) and arm's-length exchanges (thin lines). Each subsidiary may have its own network of partners as Subsidiary B or several subsidiary units may have their partners united in the same network as Subsidiaries A and C. In this case, foreign market knowledge is a driver of the internationalization with which a company, through a learning-by-doing process, understands the functioning principles of the local network and its major players (Forsgren, 2008). Foreign market knowledge also entails "information and experimental knowledge about its international operating environment" such as customers, competitors or market conditions (Yli-Renko et al., 2002). Johanson and Vahlne (2009) in the business network internationalization process model argue that the lack of institutional market knowledge and business market knowledge constitute the liability of foreigness which deals with psychic distance between the countries, and liability of outsidership respectively. In this view, the insidership into the relevant networks means company (or subsidiary) is involved in invisible patterns and is linked with the other actors of the business network, and this enables the 
internationalization. Hence the liability of outsidership may become a serious constrain for successful internationalization (ibid.).

\section{International Business Competence in MNCs}

A MNC subsidiary in a foreign country is often established as a legal entity that is independent to some extent. The subsidiary has to cope with the legislation of the country of its operations as well as with the corporate culture and subordination of the parent company. Moreover, often, the newly opened subsidiary is a small-scale firm and thus may operate in the SME sector in the host country. In other words, the subsidiary unit is an SME in the host country's market and thus we define the SIBC as "an ability to establish operations and then perform the business activities in concordance with the host country's regulations and culture”. Following the view of Hallen (1982) that international competence is required on two levels - an individual and organizational one - the SIBC consists of both the international competence of the subsidiary's CEO and the subsidiary's proficiency in host country operations. In line with Knight and Kim (2009), we consider the following four dimensions of international business competence to be applicable to the phenomena examined in this study:

International orientation is expressed in the proactive company's culture and management, which stimulates the strategically right actions and decisions in the host country's market. It corresponds to the concepts of global mindset (Nummela et al., 2004) and international growth orientation (Nummela et al., 2005), yet international orientation is particularly applicable in the context of cross-border subsidiaries as it does not presuppose a specific growth-seeking mindset from the subsidiary but, rather, it assumes that the subsidiary aligns its strategic choices with its role in the MNC.

International marketing skills refer to special efforts in the new market to communicate with the customer and to advertise the product to the right segment of customers; in other words, to 
create value (see e.g. Cavusgil and Zou, 1994; Knight and Cavusgil, 2004). The marketing skills organize the activities of the company in the way that provide inimitable value and differentiation from the competitors, which consequently brings about improvements in performance.

International innovation is the ability of the company to innovate in their processes, products and services for international markets. Innovativeness in the international context is often seen as a part of entrepreneurial behaviour in international markets (see e.g. Knight and Cavusgil, 2004). The company's R\&D and marketing intelligence can improve the performance in the particular market through achieving a leading position in technology solutions.

International market orientation refers to the responsiveness of the company towards the particular market or customer needs, thus, companies with international market orientation achieve better international performance. In the MNC context, Qu and Zhang (2015) and Kirca (2011) have found a positive relationship between the market orientation of a subsidiary and their performance, a result linking market orientation to increased competitive advantage among subsidiaries. This is achieved by focusing both on adaptation, to serve the customer's needs, and differentiation, to stay competitive. Market intelligence serves as the vital source of knowledge for the future internal developments that may lead to increased performance (Kwon, 2010; Knight and Kim, 2009).

While exporting firms and internationalizing, SMEs need to possess international business competence in order to handle export activities or internationalize; we do not yet know the extent to which it is also necessary for MNC subsidiaries located in foreign markets. We are investigating this research gap with Finnish MNCs that have their subsidiaries in Russia for several reasons. First, the short physical distance between Finland and Russia involves both countries in economic and business interaction, and Russia was for a long time the largest 
trading partner for Finland - before the financial instability of 2014 when Germany took its place. Beside the rapid development of the trade relations, 1990's became the point when Finnish enterprises have actively started to invest in Russia. Then, Finnish foreign direct investments (FDI) to Russia were equal to 2.8 billion Euros in 2013 (Statistics Finland, 2014). Second, despite their geographical proximity, Finland and Russia have distinct business environments (e.g. Ivanova and Torkkeli, 2013) and the business culture of Brazil, Russia, India, and China (the BRIC countries) is known to differ from that of developed EU countries. For instance, Russian business culture is characterized by hierarchy in company management and control systems where people in senior positions hold a substantial amount of power and responsibility (Herman Miller, 2010). Third, business adaptation of Finnish companies in Russia is defined by the relationships they have with Russian authorities (Kosonen et al., 2008). The features setting these barriers include the legislative instability that affects the company's registration process, the bureaucracy that slows down the processes of decisions' acceptance, uncertainty in the law interpretations made by the authorities and, finally, corruption. These features may make some Finnish companies leave Russia(ibid.)

\section{RESEARCH DESIGN}

For several reasons, the qualitative case study research approach was chosen to capture a relatively narrow and underexplored phenomenon of international business competence. First, case methodology has remained comparatively scarce in organizational research, yet it offers a distinctive and widely applicable methodology for studying organizational phenomena (Wadham and Warren, 2014). Applying the method contributes to a body of research in providing exemplars, in particular for the purposes of strengthening a given field research (Flyvbjerg, 2006). In doing so, the absolute number of cases is not the determining factor of the rigor of the research (Lee, 1989; Siggelkow, 2007). 
Second, the context of an MNC in the cross-border international business environment makes the research even more specific and requires a phenomenon's exploration in the natural setting. Consequently, the in-depth case study allows an interaction between the context and phenomenon's understanding (Dubois and Gadde, 2002) - its analysis in the contextual setting - and more holistic coverage of the selected companies (Ghauri, 2004). Third, we chose the abductive research approach, defined by Dubois and Gadde (2002) as "systematic combining", as it is known to be highly applicable to case studies. This approach is characterized by a stronger reliance on theory compared to an inductive approach and, simultaneously, is sufficiently remote from deductive logic. The results acquired by the method of a single case study are perceived as narrow and difficult to generalize to a wider scope. The replication in the method of a multiple-case study contributes to the generalization (Yin, 2009). Thus, we sought answers to the research question via two Finnish MNCs.

The choice of the case companies and the informants within them is a question of great importance. The centre unit of the research in the case study is a real-life system framed in bounds, thus, the data are to be acquired from different sources of information from the past (archives, news) and present (interviews, on-site observations) and the chosen cases are likely to replicate or extend the emergent theory (Eisenhardt, 1989).

We approached originally ten Finnish companies operating in Russia. Four of the companies were not able to participate because they either had just started their operations or were too busy to participate in the study e.g. due to a merger, for example. Furthermore, some of the companies were unable to provide us informants on the all three levels of investigation we were interested in (e.g. in one company the very same mangers was responsible for Russian operations both the headquarters and subsidiary level). In this paper we eventually focus on two companies; there are common characteristics for the two chosen case companies in the end: they are both business-to-business (B2B) MNCs in the construction industry, which has been 
identified by Finnish Funding Agency for Innovations TEKES (2016) to be in need for new technologies and expertise in Russia. This make the industry contextually very interesting. Both companies are headquartered in Finland, have operations spanning several countries, and both have established subsidiaries with commercialized product and production plants in Russia. In order to preserve confidentiality, the names of the case companies were altered (to Company A and B). The names of the partners of the subsidiaries or headquarters were similarly anonymized.

The respective subsidiaries of the case companies were operating in the Moscow, Saint Petersburg and Kaluga regions. An expected development considering the fact that Moscow region is the most popular destination for (FDI) in Russia with 108 companies with Finnish investments and Saint-Petersburg region is the second most popular with 214 companies with Finnish investments in 2014 (E\&Y, 2013; Rosstat, 2015). The Kaluga region is located in Western Russia, the administrative centre is Kaluga city with more than one million inhabitants. It is the third most attractive area in Russia for FDI, attracting manufacturing Western European companies with its industrial parks and via its proximity to Moscow. However, it had only nine companies with Finnish FDI in 2014 (E\&Y, 2013; Rosstat, 2015). With Moscow and SaintPetersburg being the most promoted regions in Russia by TEKES (2016), the selection of case companies from the Russian regions with a diverse number of Finnish companies is aimed at identification of prominent difference in subsidiaries' operations caused by the location. Another notable difference between the two are that in Company A, the corporate language used in the subsidiary is Russian, while with Company B the official language is English.

The MNCs themselves are relatively established companies, one having been founded in 1978 and the other in 1955. Both of the companies have founded their Russian subsidiaries within the past 10 years, and the said subsidiaries remain comparatively small in size (25 and 33 employees). Key information on the case companies is summarized in Table 1. 


\begin{tabular}{|c|c|c|c|c|c|c|c|}
\hline $\begin{array}{c}\text { Year in } \\
\text { which the } \\
\text { parent } \\
\text { company } \\
\text { was } \\
\text { founded }\end{array}$ & $\begin{array}{c}\text { No. of } \\
\text { countries } \\
\text { entered } \\
\text { by the } \\
\text { MNC }\end{array}$ & $\begin{array}{c}\text { Year in which } \\
\text { the Russian } \\
\text { subsidiary } \\
\text { was founded }\end{array}$ & $\begin{array}{c}\text { Subsidiary's } \\
\text { location in Russia }\end{array}$ & Entry mode & $\begin{array}{c}\text { Employees in } \\
\text { the subsidiary }\end{array}$ & $\begin{array}{c}\text { Corporate } \\
\text { language }\end{array}$ \\
\hline A & 1978 & 8 & $\begin{array}{c}2008 \text { and } \\
2013\end{array}$ & $\begin{array}{c}\text { Moscow and } \\
\text { Saint-Petersburg } \\
\text { The Kaluga } \\
\text { region }\end{array}$ & Green field & 25 & Russian \\
\hline B & 1955 & 4 & 2010 & Green field & 33 & English \\
\hline
\end{tabular}

Table 1. A summary of the case companies.

We conducted face-to-face interviews with the top management of the Russian subsidiaries as the main source of data and supplemented that with data from secondary sources. The interviewees are the sources of information for what they have observed (as this is impossible for the researcher to observe), with each informant being encouraged to tell a story or to give an explanation, episode or linkage based on his or her unique experience (Stake, 1995). In both cases, the interviewee was the company CEO. We considered these people key informants because the international competence of the subsidiary is reflected in the unit's operations under their control. Moreover, the current CEOs have personally established the Russian operations from the beginning.

In order to cover the recent political and business environment changes in Russia, we collected the empirical data between May and June 2013 for Company B and between March and April 2015 for Company A. This research setting requires the information obtained from three parties in each case - the Russian subsidiary unit, the MNC's internal party (their Finnish headquarters) and a party external to the MNC (the Russian subsidiary's partner). All in all, four sets of questionnaires were developed - one for headquarters, one for subsidiaries' partners and two (one structured and one semi-structured) for the subsidiaries resulting altogether in six interviews - three for each of case companies. The interviews with subsidiaries' representatives lasted circa one and a half hours each and covered a range of specific issues, including the subsidiary's establishment process, the business adaptation strategy and operations concerning the local market, partners, customers, corporate culture and employees. 
To ensure the validity and reliability of this research, we applied triangulation strategy, as it helps in providing a relatively complete, holistic and contextual description of the study object (Ghauri, 2004). In a case study, it further allows for information from several sources to be examined and validated from different angles. In the situation when several cases are selected for the research, the within-case analysis is executed first, followed by cross-case analysis to provide a comparison (Creswell, 2013).

Prior to analysis, the interviews were transcribed by the researcher. The use of computer assisted qualitative data analysis software during the processes of qualitative data collection and analysis increases the trustworthiness through the transparency of the procedures (Ghauri and Grønhaug, 2010). The formalization of the procedures of processing the qualitative data will contribute to the reliability of the results (Sinkovics et al., 2008). Therefore, we also conducted the data coding process using NVivo10 software during the primary and secondary data analysis phases. We employed coding for the whole data range and applied two coding strategies - a priori and a posteriori - simultaneously for codifying the data according to the existing theory but not omitting the topics emergent from the data. The coding process was iterated until no more themes could be retrieved from the data, in line with the technique by Sinkovics et al. (2005).

\section{EMPIRICAL RESULTS}

In order to clarify the empirical results on international business competence development, we first describe the extent of business and cultural adaptation performed by the companies when establishing their Russian subsidiaries. These adaptations underlie the competence development process, which is described subsequently.

\section{$\underline{\text { Business and cultural adaptation }}$}


Company A's parent company was established in Finland in the late 1980s as a window renovation company. Now the company's primary business fields are frameless balcony glazing, terraces, glass and aluminium production and installation. The parent company has been working in Russia since 1999 through the representative office in Moscow. Later, it was forced to close down one in 2001 due to the tough time experienced after the 1998 crisis, and they continue their operations through local resellers. In 2007, the present Russian CEO, who today has about 16 years of experience of Russian operations, registered the affiliate company and the Moscow subsidiary, which later become a regional headquarters, was opened. Five years later a branch of the Moscow subsidiary was established in Saint-Petersburg. Nowadays, the company has production in Russia, licensed by the parent company and using their registered trademark, and the subsidiary pays a royalty fee to the parent company. Its geographical scope is the whole of Russia and the local entity performs general management, production and sales functions.

Preparation for opening the subsidiaries in Russia took about seven months. This period was dedicated to collection of information, for example, actively acquiring information from the resellers, open sources on the Internet, Finnish construction companies and the Finnish-Russian Chamber of Commerce. The paperwork was outsourced to a Finnish-Russian company; a consultancy with "Russian veterans" helped a lot in business plan arrangements:

"I would like to emphasize one thing - without reliable, experienced professional Russians who have worked with us earlier, we wouldn't have succeeded." - Company $A$

There was close cooperation with one of the resellers due to the strategic plan of opening the joint stock, but it has failed. Nevertheless, the companies remained close partners and Company A hired four people to work in its Moscow subsidiary from this reseller. While old contacts were used for entering the market, the establishing of new contacts was not problematic for the newborn company. The enlargement of the reseller network was mainly done through the 
participation in big exhibitions for three years in a row. That partially supports the finding of Yli-Renko et al. (2002) that the contacts of a company's management have a positive relation with their knowledge of a foreign market and entry mode experience. According to business network view it is believed that prior experience of the company's top management provide a vital knowledge and thus, important for the successful internationalization (Johanson and Vahlne, 2009).

The company's development strategy in Russia meant entering the reselling market first and entering the project business market two years later. By chance, the company entered the project market at the beginning of its operations and what may look like a success was actually a problem for the management:

"We started with resellers but at the very same time we were obliged to take care of projects and our knowledge at that time was zero: What belongs to logistics? What belongs to legislation? What belongs to the tests and documents? That was more or less a bigger question and contradicted our business plan. We were trapped in the project business by the way." - Company $A$

Even though Company A relies on the rich personal experience of the Russian CEO, the small two-year-old Saint-Petersburg subsidiary was still lacking the necessary knowledge in the methods of doing business.

Company A has only a few employees who have studied abroad (and none have international working experience). An international background is not a priority in the recruiting process; instead, motivation is valued. The company agrees that a greater level of international knowledge is essential for the company's functioning as it can be used to understand the international players, their management systems and decision-making process. Yet for now, the employees' local knowledge has a higher priority:

"I would say that without local knowledge of the market, local knowledge of the culture and language, you can't do any business in Russia. [...] Mainly, we are doing business in the local construction business; you have to know the rules, the players, the culture and so on." - Company A 
Company B's parent company is the largest European company specializing in the production of packaging materials and polymer-based agricultural feed. Established in mid-1950s as a family company, today it is a group of companies consisting of four subsidiaries, four joint ventures and two real estate companies.

The local CEO opened the first subsidiary in Russia mostly individually, and the information acquisition process has been done well in advance. Before signing the turnkey contract of the subsidiary's establishment, the information collection had been performed:

"Of course we had the knowledge of the general way of working. Then I came here early, rather early, and I looked around and tried to learn something. [...] I was getting [information] by talking to administration people, customs people, customers, suppliers, logistic companies." - Company $B$

The company was offered a place in the industrial park with turnkey premises (that included a production plant, roads, infrastructure, water supply, IT and offices). This appeared to be one of the main reasons in the decision to come to exactly this location in the Kaluga region:

"We don't need to get any expertise in negotiating about everything like electricity or water - they are just a part of the deal." - Company $B$.

Additionally, Company B supports Company A's above-stated idea that Finnish companies have to find the "right persons", meaning local people who will assist with establishing the business in Russia. Nevertheless, the subsidiary's management has sometimes had certain difficulties with understanding the Russian legal procedures, such as customs regulations. The local CEO sees the solution in following the law and in making "everything as instructed". This Finnish cultural feature refers to Hofstede's (2015) uncertainty avoidance, indicating the willingness of Finns to prevent undetermined situations leading to a personal need for setting the rules and following them.

Furthermore, there seem to be no problems despite the fact that the local CEO does not speak Russian because the subsidiary's employees are "always ready to help". The company's partner, 
who noted that generally there are no issues in using English in the communication process, confirmed this. The internationally experienced subsidiary's employee being a Russian, understands the CEO's way of thinking and may explain him the Russian reality of "how things are made here".

"[The employees] are fantastic experts. They know what is needed and they will tell you everything in advance. Feed them with material and information and they are experts; they will tell you what is missing." - Company $B$

Both international and local employees' expertise are crucial for succeeding in the Russian market. Combined they help to secure a proper understanding of the local culture, smooth business operations' flow and the concordance of employees with the company values:

"We have to have people who know how to talk to foreigners and how to get money going from abroad to us or vice versa, and trucks [that] are sent here and there. You need a good mix." Company $B$

Another reason for the subsidiary's smooth operations in their particular area is having the favour of the region's administration, gained in order to attract FDI:

"Administration are interested in what we are doing. [...] if I see the vice-governor on the street, he talks to me. He remembers me, a small company representative. [...] the governor is always interested. [...] [They] know that they need to run fast and work hard to get investors here and for this area to flourish." - Company $B$

To sum up, no significant cultural misunderstandings have occurred in the companies while dealing with their Russian counterparts and the expatriates in the managerial positions of the subsidiaries have demonstrated a deep understanding of Russian cultural issues and had the flexibility needed in order to adapt to the "rules of the game". However, the issue of "time" has arisen in several interviews during the research process. The speed of business in Russia is seen by the interviewees as rapid and indicated as the biggest difference between the Russian and the Finnish ways of doing business. The subsidiaries' partners brought up this issue, and they mostly agree that the decision-making process takes longer in a Finnish company compared to a Russian one: 
"[Finns] are thinking for very long, weighing up the options, [deciding] if they need something or not. In Finland they may have time, but we do not have that time. Some things happen by chance.

[...] Thinking for a long time will lead to further arguing and philosophizing. So we are more oriented to action than to a very lengthy weighing up of options. <...> Finns weigh things up every time. [...] Different speed; we have it much faster." - Company A's partner

"In terms of cultural differences, there are some differences in mentality. A Russian needs something already yesterday; and then a Finn thinks for a very long time and considers everything." - Company B's partner

In the opinion of one partner, this problem has its roots in the "high level of management", meaning much of the coordination between the parties inside the subsidiary is slowed down by having to communicate about every single decision with the parent company in Finland. In the study of managerial sense-making in Finnish and Russian SMEs (Ivanova and Torkkeli, 2013) Russian culture's schema of hurrying along and seeking profit have been called the "need to act quickly" and "profit orientation" respectively. The roots for common managerial behaviour are seen in historical events, for instance, in the economic upheaval of Russia in the 1990s.

Overall, the case companies understand that the Finnish way of operating a business cannot be fully copied in Russia as a standardized way of operation and that the different pace of business leads to rapid changes. This situation allows companies to only set up the development direction rather than perform long-term detailed planning (which they keep doing in Finland).

\section{The SIBC}

\section{International market orientation and international innovation}

International market orientation refers to the extent of orientation towards foreign markets, customer needs and preferences, while international innovation refers to the product modifications and R\&D activities related to market adaptation and customer feedback.

The possible differences of the Russian market compared to the Finnish market caused additional tests and research of the local market needs for Company A. Together with that, the certifications and product registrations required by Russian authorities were obtained. The 
company has modified its product at the beginning of its Russian operations, due to the different requirements set for the installation process: the standard process appeared expensive and insufficient in Russia and thus, product modification was done by the parent company in Finland to make the installation much simpler and cheaper. However, this modification has not brought any significant changes to the product, and the degree of product standardization allows introducing it to any other market "without any big problems".

Company A's parent company collects customer feedback in Finland, Norway and Sweden on a regular basis in the after-sales period. In Russia, the subsidiary acquires the resellers' opinions, facilitates the discussions during the events and at the projects' closing meetings but does not regularly collect feedback from final users.

Company B has done partial modifications driven by the high product price for the Russian market. The replacement of raw materials with local and Belorussian substitutes have reduced the price. Other than that, the product remained the same as the one sold in Finland, which allows the high degree of product standardization. Moreover, the product with substituted raw materials developed in Russia, has been applied in the Sweden and German markets by the Finnish headquarters. The headquarters is responsible for product developments in the company, however, the subsidiary is involved in this process together with its customer.

Both companies have adjusted their products to the Russian market or customer preferences and hence demonstrated responsiveness to the market needs.

\section{International orientation}

In the original setting, the proactive and entrepreneurial behaviour (which is sometimes close to being aggressive) of the SME managers in international markets constitutes the international orientation. In the MNC context of this research, the local leaders determine the international orientation of the subsidiary, encompassing their attitudes towards the business environment 
and their willingness to accept the challenge of the local environment. In practice, it is manifested as the ability of expatriates' acculturation or the adaptation to the local culture, in line with the division of expatriate types into four groups (see Lasserre, 2012). An expatriate may express an attitude towards the new culture ranging from the high preservation of one's culture and neglecting the new one to the high assimilation into the new culture and losing the connection with one's culture. In between, there are two attitudes either closer to the first one ("fight") or second one ("fit") without the strong imbalance.

In Company A, the Country Director is the actual decision-maker who leads the both subsidiaries. His international orientation and valuable experience enable both the smooth procession of operations by the subsidiary in the Russian business environment and consistent adherence to the corporate strategy. Moreover, his desire to work "hand in hand" with the partners and his openness towards mutual aims may serve as a demonstration of his personal orientation towards Russia. In Company B, the CEO refers to attitude as the main manifestation of international orientation:

"It's a question of attitude. If the attitude, for a newcomer, is that 'everything is difficult here. It's better in Finland, back home.' So it is difficult. If the attitude is that 'this is my location, my home where I work and where I try to do my best.' Then it works." - Company B

Overall, the expatriates in the case companies have a cosmopolitan "fit" attitude. Such expatriates are interested in adapting to the foreign culture and are able to obtain new contacts. As a result, they exhibit the ability to possess a set of balanced local and global competencies.

\section{International marketing skills}

For the managers of internationalizing SMEs, international marketing skills mean the ability to bring value for the international customers through successful implementation of marketing activities. Here, the ability to attract new customers either through the marketing or active networking is considered. While reaching customers from abroad in advance may be 
challenging for SMEs (as they may lack the sufficient local knowledge), subsidiaries operating in the local market are more capable of performing marketing activities by themselves.

In the main B2B context of Company A's operations, there are two main groups of customers - project customers and resellers. Neither of these types require special marketing activities but rather use reference marketing and direct communication. The same holds for Company B, which has its localized website with the full product information and participates in industryrelated exhibitions but primarily relies on the references and establishing contacts.

For operations in the business-to-consumer (B2C) context, Company A has divided the final users into three target segments based on their welfare (and thus their capability to buy the company's product). Nevertheless, no active marketing activities, except for a full range of information on the localized website, are performed for the product promotion in the Russian B2C market. This responsibility is outsourced to the resellers who use their own marketing channels. Thus, mutual marketing activities aim at acquiring more partners and customers.

\section{DISCUSSION AND CONCLUSIONS}

Taken together, the results of the empirical analysis suggest that the indicators of international business competence are at a high level for both companies. The underlying dynamic is that MNC subsidiaries derive advantages from their local presence and local employees, advantages unique to the MNC subsidiary environment, advantages that facilitate the high level of the SIBC. The development of the SIBC, as derived from the data, is presented in Figure 2. 


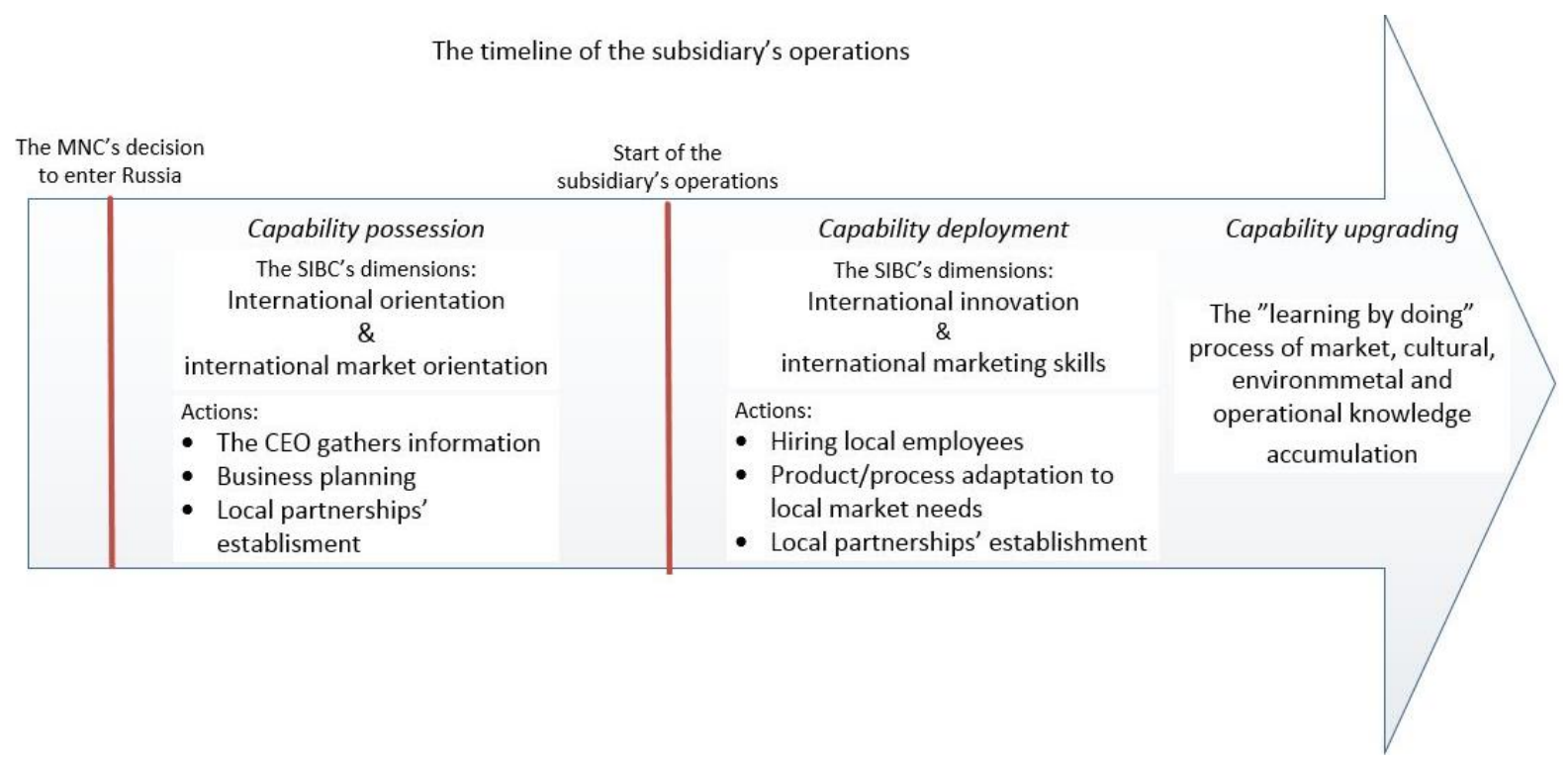

Figure 2. The SIBC's development over the time of the subsidiary's operations.

We note that the actions taken evolved from individual-level competence (prior to and during the subsidiary opening) through to primarily organizational-level competence (during the continued operations of the subsidiary in the host country). Following the Figure 2, SIBC is expressed as a dynamic capability defined by Luo (2000), and it has three required components. Capability possession and capability deployment are expressed in obtaining the distinctive resources and their smart allocation. Both result in the capability upgrading which in this case is a "learning-by-doing" process. Such learning process can also be called an experiential learning which in business network view is considered as a main mechanism of internationalization (Johanson and Vahlne, 2009).

The overall results suggest that, in order to avoid the challenges associated with the differences in the operational business environment between a culturally distant country and the MNC's home country (e.g. those between that of a Finnish MNC and its subsidiary in Russia), the subsidiaries need to possess and develop international business competence. As seen from Figure 2, consultation of knowledgeable locals through establishing the partnerships must occur before and during the early stages of foreign market entry. In this, the "classic IB proposition" 
about market knowledge and networks is supported (e.g. Johanson and Vahlne, 1977; 2009). Besides the active information allocation and research towards the future business operation, the parent company is advised to reflect upon the experience of similar companies in the area of interest.

After the start of operations, the local employees with international and local expertise are considered as a unique asset that will benefit the subsidiary in two ways. First, local expertise provides a thorough understanding of the local issues and cultural patterns, which are often inaccessible for the expatriates. This will also contribute to the increase of subsidiary's local embeddedness rapidly. Second, international expertise ensures the conformity of the employee to the corporate culture, which in this research originates from a country with a Western business culture and principles. The influence of the local authorities' policies on the subsidiary establishment process and future operations, as raised in one of the empirical cases, should be explored further since a similar significance was not evident with the case in another region. Product and process adaptation is beneficial for the whole MNC, either in cost reductions or operation effectiveness.

Summing up, the process of and developing all four dimensions of the SIBC before, during and after the start of operations is crucial. It facilitates the subsidiary becoming embedded in the host country environment and allows further knowledge acquisition through the learning-bydoing process.

Overall, Hofstede's cultural dimensions (2015) of Finland and Russia are reflected in cultural differences that affect the business operations of the subsidiary and relationships with the partners. Due to these differences, the higher degree of international business competence of the subsidiary is crucial for its localization process when the cultural distance between the home and host countries is large. The description provided by the data has allowed us to further 
illustrate the concrete ways in which the case company subsidiaries have developed their international business competence in practice.

\section{$\underline{\text { Theoretical contribution }}$}

While the literature makes it clear that exporting firms and internationalizing SMEs need international business competence in order to handle export activities or internationalize (cf. e.g. Knight and Kim, 2009), our research questions (How does the development of international business competence in the subsidiaries of MNCs occur? and To what extent should the subsidiaries possess international business competence during their establishment and in subsequent operations?) focused on the internationalization of small units of larger entities. These dynamics are important to investigate, as subsidiary capabilities impact the operations of multinationals (e.g. Andersson, 2003; Phene \& Almeida, 2008). However, while international business competence has been found to be a crucial capability for companies aiming to conduct international business, it has not been illustrated in the MNC-subsidiary context before. In doing so, this study highlights both the dynamics of subsidiary capability development overall, as well as extends the range of beneficial capabilities to include international business competence of subsidiaries. Thus, this research contributes to expanding research on international business competence and dynamic capabilities, research that has so far mainly considered these concepts in terms of export activities (Belich and Dubinskiy, 1995) or SMEs' internationalization (Knight and Kim, 2009). We further add to this by extending the research on international business competence to the MNC context by describing how such a competence can be developed in practice and by further highlighting the ways in which MNCs and their subsidiaries can operate in a distinct developing business culture, such as Russia. Examining the process of capability development empirically also provides added weight into the literature on dynamic capabilities, which has historically been rather conceptual and abstract (e.g. Barreto, 2010). 
In this way, the present study contributes to explaining MNCs' expansion through exploring the competences of an MNC subsidiary. The expansion of an MNC and the opening of the new affiliate companies are tightly connected with the potential value that these actions bring to the focal company. In order to increase the value of subsidiaries in each particular country, this research suggests paying attention to the development of international business competence.

\section{$\underline{\text { Managerial implications }}$}

For MNCs' top management, this research provides insights into the Russian cultural issues that may constrain or influence the smooth operations of a foreign MNC's subsidiary. First, the research indicates that there is a difference in the institutional environments of different Russian regions, particularly, the orientation of local authorities towards the attraction of FDI may contribute to the easier start of operations. Then, there have not been found dramatic difference if subsidiary's CEO speaks local language or not mainly, because in the studied case companies, the local employees are that crucial resource which handles the communication-related issues. However, the managers of the parent companies and the local managers of the subsidiary should consider the significance of cultural differences between Finnish and Russian cultures identified in this study. The notable one, which requires the possession of SIBC in Russia is the high pace of the business environment change and the decision-making process which are accepted by most of the market players. This poses additional pressure for the subsidiary's business operations and even causes Russian partners' dissatisfaction when a long time is taken for decision approval by the Finnish top management.

\section{$\underline{\text { Limitations and suggestions for further research }}$}

This research has certain limitations that should be considered when interpreting the results. First, the selected research method may impose boundaries on the validity of the results, as the extent of generalizability is constrained by the number of cases utilized in this study. Moreover, 
the Finnish-Russian context appoints limitations associated with the country-specific character. Thus, the research from the three regions cannot be scaled to the whole of Russia due to the drastically different environments of the regions of the country.

Further studies would benefit from the enlargement of the sample size and proper categorization. While in the research the subsidiaries in Russia were taken from certain regions and all of them perform B2B operations, exploring the influences of different factors might be a valuable contribution to research and will ensure homogeneity. It could be proposed to additionally differentiate the sample subsidiaries by the position in the MNC, time of operations, entry mode and type of business or specific industry. Furthermore, it could also be interesting to consider the financial performances of the MNCs and their subsidiaries. Taking into account the recent Russian economic instability, the focus on the effect of SIBC in terms of financial crisis may need to be considered.

\section{Conclusions}

Summing up, our study has shown that SIBC is possessed by the subsidiaries entering the foreign markets, and it is both constituted from the parent MNC's contribution in terms of brand name, resources, licences and corporate philosophy, and personal country-related experience of local CEO. Most importantly, the development of SIBC is a continuous process which starts prior the start of subsidiary's operations and is of a great concern during the start of operations in the host country. While SIBC as a dynamic capability leads to the continuous learning-bydoing process of knowledge accumulation in the host country, some factors of local business environment and culture may possess the influence of a different degree and direction on the SIBC development. Further research is necessary to identify the organizational and business environmental antecedents that facilitate or constrain the development of SIBC dimensions. 
Knowledge about these antecedents could guide the MNC internationalization and (small) subsidiary's establishment process in culturally distant countries. 


\section{REFERENCES}

Andersson, U. (2003) 'Managing the transfer of capabilities within multinational corporations: the dual role of the subsidiary', Scandinavian Journal of Management, Vol. 19, No. 4, pp.425442.

Andersson, U., Forsgren, M. and Holm, U. (2001) 'Subsidiary embeddedness and competence development in MNCs a multi-level analysis', Organization Studies, Vol. 22, No. 6, pp.10131034.

Andersson, U., Forsgren, M. and Holm, U. (2002) 'The strategic impact of external networks: subsidiary performance and competence development in the multinational corporation', Strategic Management Journal, Vol. 23, No. 11, pp.979-996.

Autio, E., Sapienza, H.J. and Almeida, J.G. (2000) 'Effects of age at entry, knowledge intensity, and imitability on international growth', Academy of management journal, Vol. 43, No. 5, pp.909-924.

Barreto, I. (2010) 'Dynamic capabilities: a review of past research and an agenda for the future', Journal of Management, Vol. 36, No. 1, pp.256-280.

Belich, T. and Dubinsky, A. (1995) 'Factors related to information acquisition in exporting organizations', Journal of Business Research, Vol. 33, No. 1, pp.1-11.

Cavusgil, S. and Zou, S. (1994) 'Marketing strategy-performance relationship: an investigation of the empirical link in export market ventures', Journal of Marketing, Vol. 58, No. 1, pp.1-21.

Creswell, J. (2013) Qualitative Inquiry and Research Design: Choosing among Five Approaches, 3rd ed., SAGE Publications, Los Angeles. 
Dubois, A. and Gadde, L. (2002) 'Systematic combining: an abductive approach to case research', Journal of Business Research, Vol. 55, No. 7, pp.553-560.

Eisenhardt, K. (1989) 'Building theories from case study research', The Academy of Management Review, Vol. 14, No. 4, pp.532-550.

Eisenhardt, K. and Martin, J. (2000) 'Dynamic capabilities: what are they?', Strategic Management Journal, Vol. 21, Nos. 10-11, pp.1105-1121.

Ernst \& Young's (2013) Attractiveness Survey, Russia 2013, Shaping Russia's Future [online] http://www.ey.com/Publication/vwLUAssets/2013-Russia-attractiveness-survey-Eng/\$FILE/ 2013-Russia-attractiveness-survey-Eng.pdf (accessed on 5 January 2016).

Flyvbjerg, B. (2006) 'Five misunderstandings about case-study research', Qualitative Inquiry, Vol. 12, No. 2, pp.219-245.

Forsgren, M. (2008) Theories of the Multinational Firm, Edward Elgar, Cheltenham, Glos, UK.

Ghauri, P. (2004) 'Designing and conducting case studies in international business research', in Marschan-Piekkari, R. and Welsch, C. (Eds.): Handbook of Qualitative Research Methods for International Business, 1st ed., Edward Elgar, Cheltenham, UK.

Ghauri, P. and Grønhaug, K. (2010) Research Methods in Business Studies, Financial Times Prentice Hall, New York.

Hallén, L. (1982) 'International purchasing in a small country: an exploratory study of five Swedish firms', Journal of International Business Studies, Vol. 13, No. 3, pp.99-112.

Herman Miller (2010) Culture and Work Styles in the BRIC Countries, Research summary [online] https://www.hermanmiller.com/content/dam/hermanmiller/documents/ceu/ceu_selfstudy_ 
BRIC_Countries.pdf (accessed 25 January 2016).

Hofstede, G. (2015) Cultural Dimensions Countries Comparison, website [online] http://geerthofstede.com/countries.html (accessed on 4 January 2016).

Ivanova, M. and Torkkeli, L. (2013) 'Managerial sensemaking of interaction within business relationships: a cultural perspective', European Management Journal, Vol. 31, No. 6, pp.717727.

Johanson, J. and Vahlne, J-E. (1977) 'The internationalization process of the firm: a model of knowledge development and increasing foreign market commitments', Journal of International Business Studies, Vol. 8, No. 1, pp.23-32.

Johanson, J. and Vahlne, J-E. (2009) 'The Uppsala internationalization process model revisited: from liability of foreignness to liability of outsidership', Journal of International Business Studies, Vol. 40, No. 9, pp.1411-1431.

Kirca, A. (2011) 'The effects of market orientation on subsidiary performance: empirical evidence from MNCs in Turkey', Journal of World Business, Vol. 46, No. 4, pp.447-454.

Knight, G. and Cavusgil, S. (2004) 'Innovation, organizational capabilities, and the born-global firm', Journal of International Business Studies, Vol. 35, No. 2, pp.124-141.

Knight, G. and Kim, D. (2009) 'International business competence and the contemporary firm', Journal of International Business Studies, Vol. 40, No. 2, pp.255-273.

Kogut, B. and Zander, U. (1993) 'Knowledge of the firm and the evolutionary theory of the multinational corporation', Journal of International Business Studies, Vol. 24, No. 4, pp.625645. 
Kosonen, R., Kettunen, E. and Kotilainen, J. (2008) Managing the Relations of Business Firms with the State across Spatial Institutional Discontinuities: Finnish Firms in the Rapidly Developing

Markets of Russia, Estonia and China, Working paper, Publishing House of SU HSE, Moscow.

Kuivalainen, O., Puumalainen, K., Sintonen, S. and Kyläheiko, K. (2010) 'Organisational capabilities and internationalisation of the small and medium-sized information and communications technology firms', Journal of International Entrepreneurship, Vol. 8, No. 2, pp.135-155.

Kwon, Y. (2010) 'Market orientation of Korean MNC subsidiaries and their performance in the Chinese and Indian markets', International Marketing Review, Vol. 27, No. 2, pp.179-199.

Lasserre, P. (2012) Global Strategic Management, Palgrave Macmillan, Houndmills, Basingstoke, Hampshire.

Lee, A. (1989) 'A scientific methodology for MIS case studies', MIS Quarterly, Vol. 13, No. 1, p.33.

Luo, Y. (2000) 'Dynamic capabilities in international expansion', Journal of World Business, Vol. 35, No. 4, pp.355-378.

Nummela, N., Puumalainen, K. and Saarenketo, S. (2005) 'International growth orientation of knowledge-intensive SMEs', Journal of International Entrepreneurship, Vol. 3, No. 1, pp.518.

Nummela, N., Saarenketo, S. and Puumalainen, K. (2004) 'A global mindset - a prerequisite for successful internationalization?', Canadian Journal of Administrative Sciences/Revue Canadienne des Sciences de l'Administration, Vol. 21, No. 1, pp.51-64. 
Phene, A. and Almeida, P. (2008) 'Innovation in multinational subsidiaries: the role of knowledge assimilation and subsidiary capabilities', Journal of International Business Studies, Vol. 39, No. 5, pp.901-919.

Rosstat (2015) Website [online] http://www.gks.ru/bgd/regl/b15_14p/Main.htm (accessed 5 May 2016).

Siggelkow, N. (2007) 'Persuasion with case studies', Academy of Management Journal, Vol. 50, No. 1, pp.20-24.

Sinkovics, R., Penz, E. and Ghauri, P. (2008) 'Enhancing the trustworthiness of qualitative research in international business', Management International Review, Vol. 48, No. 6, pp.689714.

Sinkovics, R., Penz, E. and Ghauri, P. (2005) 'Analysing textual data in international marketing research', Qualitative Market Research: An International Journal, Vol. 8, No. 1, pp.9-38.

Statistics Finland (2014) Foreign Direct Investments in 2013, 18 November [online] http://www.stat.fi/til/ssij/2013/ssij_2013_2014-11-18_kat_001_en.html (accessed 17 May 2016).

Teece, D., Pisano, G. and Shuen, A. (1997) 'Dynamic capabilities and strategic management', Strategic Management Journal, Vol. 18, No. 7, pp.509-533.

TEKES (2016) Opportunities in Russia [online] http://www.tekes.fi/en/programmes-and services/grow-and-go-global/russia/ (Accessed 5 May 2016).

Qu, R. and Zhang, Z. (2015) 'Market orientation and business performance in MNC foreign subsidiaries - moderating effects of integration and responsiveness', Journal of Business Research, Vol. 68, No. 5, pp.919-924. 
Wadham, H. and Warren, R. (2014) 'Telling organizational tales: the extended case method in practice', Organizational Research Methods, Vol. 17, No. 1, pp.5-22.

Yin, R. (2009) Case Study Research, Sage Publications, Los Angeles, Calif.

Yli-Renko, H., Autio, E. and Tontti, V. (2002) 'Social capital, knowledge, and the international growth of technology-based new firms', International Business Review, Vol. 11, No. 3, pp.279304. 